\title{
4.6 Identification of PhD students' subject specific and generic competences and their integration in EAP syllabus
}

Abstract. The aim of the paper is to provide an analysis of the most important subject specific and generic competences needed within a framework of EAP Syllabus for a successful implementation in the further PhDs students' academic and professional life. Although some attempts have been made to address the issue, the previous investigations were not focused on EAP-related competences. From the quantitative and comparative analyses, there were identified basic competences. The pre-course and post-course surveys were carried out to compare the PhDs' expectations with competences developed and implemented in real life situations. The study shows that $\mathrm{PhDs}$ are able to generate competences needed for the course, analyse them and assess own achievements in the process of learning.

Key words: Doctoral education, EAP, competences, $\mathrm{PhD}$ students, survey

\subsubsection{Introduction}

Almost a year ago, in September 2020, the Ministry of Education and Science of Ukraine posted a draft of 'Strategy for the Development of Higher Education of Ukraine for 2021-2031' (Ministry of Education and Science of Ukraine Project) on its official website, the document was prepared pursuant to the Order of the President of Ukraine №210/2020 “On the Improvement of Higher Education in Ukraine”. There has been an increased recognition that more attention needs to be paid to the level of development of science as a determining factor for the progress of Ukrainian society. This necessitates the priority of the PhDs support creating conditions for the realization of their intellectual potential in science and technology, ensuring Ukrainian $\mathrm{PhD}$ students will be able to use national and world scientific achievements to meet academic, social, economic, cultural and other needs. Although the indicators of how to assess one or another competence were not properly developed and described, in particular the indicators which can value the competences developed in the framework of teaching English for Academic Purposes (EAP). 
The European Union regards the competences development as one of the main direction for supporting economies with skilled workforce, for this purpose the opportunities should be given to university graduates to master those skills and enter the labour market with dignity. The PhDs with their skills, knowledge and expertise are considered to be on the top of the University graduates pyramid and represent the 'brain' and great potential for both national and global societies.

The Tuning project's approach makes a distinction between generic competencies (GC) and subject specific ones (SSC), although it is accepted that key outcomes of university curricula will be subject-related competences. Tuning project's survey demonstrated that employers, graduates and academic staff agreed on generic competences, from a range offered in a questionnaire, which are the more relevant ones, although they differed slightly the importance of some of them.

Presently, the importance of the generic competences is widely understood, but understanding of the concept alone is insufficient. The heart of the problem lies in the implications a competence-based approach has for teaching and learning, i.e. the University teachers should investigate and implement the appropriate teaching methods, develop learning activities to foster competences in terms of knowledge, understanding and skills, and create the measurable ways of competencies assessment.

In general, many studies, research reports, surveys highlighted a problem the University graduates face with, in particular a skill shortage after graduating from universities (Jorre de St Jorre \& Oliver, 2018; Matthews and Mercer-Mapstone, 2016; Hill at al., 2018; Bogle, Dron, Eggermont and Willem van Henten, 2010). However, fewer publications focused on competences actually developed and implemented in major disciplines, especially at the doctoral level.

Barthélémy Durette (2014) presented the results of a survey on PhDs competencies conducted on $2794 \mathrm{PhDs}$ who graduated from universities in France and determine the 'core' competencies of doctorate holders, i.e. the competencies that have the same probability of being developed through the $\mathrm{PhD}$ irrespectively of the discipline, the date of graduation and other factors. This analysis provides a sound basis to define the outcomes of doctoral education in France in terms of competencies. 
Amor \& Serrano Rodríguez (2019) compared generic competences of different groups: students, teaching staff and the groups comprising graduates. The obtained results demonstrate that certain competences from the Instrumental Competences, i.e. competence in a foreign language and technological competency, are perceived to be less developed.

In fact, the $\mathrm{PhDs}$ curricula are still focused on teaching traditional scientific skills rather than paying attention to generic competences in particular of those ones which can be developed in the frameworks of English for Academic Purposes (EAP) course.

Definition of the term 'generic competence'. In the Tuning Project, which was the driving force behind the curricular reforms in Higher Education in Europe, there was given a definition of both specific and generic competences:

Competences are obtained or developed during the process of learning by the student/learner. In other words competences represent a dynamic combination of knowledge, understanding, skills and abilities. Fostering competences is the object of educational programmes. Competences will be formed in various course units and assessed at different stages.

Competences can be distinguished in subject specific and generic ones. Although Tuning acknowledges to the full the importance of building-up and developing subject specific knowledge and skills as the basis for university degree programmes, it has highlighted the fact that time and attention should also be devoted to the development of generic competences or transferable skills. This last component is becoming more and more relevant for preparing students well for their future role in society in terms of employability and citizenship.

Zabalza (2011) suggested the inclusion of generic competences to all university educational itineraries, although it was mentioned that they might at first appear to have nothing in common with being educated in a particular discipline, but in the upshot generic competences prove to be tremendously valuable for the integral education and imply great relevance for professionals.

Presently Tuning distinguishes three types of generic competences (Tuning Educational Structures in Europe, Competences): 
Instrumental competences: cognitive abilities, methodological abilities, technological abilities and linguistic abilities.

Interpersonal competences: individual abilities like social skills (social interaction and co-operation).

Systemic competences: abilities and skills concerning whole systems (combination of understanding, sensibility and knowledge; prior acquisition of instrumental and interpersonal competences required).

The aim of this research is: (1) to enhance understanding of indispensable $\mathrm{PhDs}$ ' competences in the framework of EAP learning and teaching at University's Doctorate level; (2) to indicate EAP areas for competences development with further implementation into EAP Syllabus.

\subsubsection{Methods of the study}

The present article analyses the data collected from PhDs specializing in Natural, Exact Sciences and Humanities in Odesa I.I. Mechnikov National University between 2017 and 2021. The participants of the study were the first- and second-year Doctorial candidates studying EAP course amounting 180 hours. Two different methods were used to collect and analyse the data received the surveys. In the first stage, as the precourse activity $\mathrm{PhDs}$ were offered to point out those EAP-related and generic competences which they reckon as the most valuable and should be developed throughout the EAP course. Prior the completing the questionnaire, PhDs were explained the difference between specific and generic competences, there was welcomed team working and sharing ideas with peers, although no competences were declared in the questionnaire in advance.

The questionnaire consisted of two questions:

Question 1: Will you, please, enumerate specific competences you would like to develop during EAP course. The competences should be expressed in the prioritized, bullet-point way, in quantity from 3 to 5.

Question 2: Will you, please, enumerate generic competences you would like to develop during EAP course. The competences should be expressed in the prioritized, bullet-point way, in quantity from 3 to 5. 
Quantitative and qualitative analyses were used to process the resulting 27 competences, group them into two main categories: subject specific (i.e. EAP-related) and generic competences where the latter ones were also subdivided into Instrumental, Interpersonal and Systemic in accordance with Tuning basic types taking into consideration the PhDs' possibility of describing the similar competences in synonymic way. Then the PhDs' questionnaires were analysed by counting the frequencies of competence mentions and setting up the order of their priority (see Table $1)$.

In the second stage of the analysis, after collecting and processing the data of the first survey, the research participants were provided with the second questionnaire where the competences of both categories were listed in full compliance with EAP Syllabus. Following this, Doctorial candidates were asked to rank them starting with the most important ones towards the less important (see Table 2, Pre-course survey).

Finally, post-course survey was carried out to investigate the participants' opinion on the quality of competences development within EAP course and the most important aspect - their real-life implementation within the period of participants' studying and writing a $\mathrm{PhD}$ thesis (see Table 3, Post-course survey, column 3).

\subsubsection{Results}

The results of the research are presented in Tables 1,2 and 3. Then two bar charts were built to compare of PhDs' preferences with existing competences stated in EAP Syllabus (Fig. 1 and Fig. 2). The bar chart (Fig. 2) also illustrates the factual realization of competences in real-life situations, the participants' positive responses were presented by crosshatching bar in percentage.

Table 1 shows that the most frequently cited category is SSC 'Good written and oral communication in academic English', it was mentioned by $46.3 \%$ of $\mathrm{PhDs}$. Second position is occupied by the SSC 'Writing scientific papers in English' (24\%). Generic competences 'Ability to perceive and process a great deal of information' and 'Ability to understand and analyse the innovations in the specific field' were mentioned in the third and fourth positions respectively. Finally, the abilities in "Networking and effective cooperation with peers, teachers, scientific supervisors' and 'Knowledge 
about papers submission to international editions' are declared by $\mathrm{PhDs}$ as necessary for development GC competences. It can be observed from Table 1 that four GCs constitute the majority among six top competences generated by $\mathrm{PhDs}$.

Table 1.

SSC and GC: Rating of importance from PhDs' point of view

\begin{tabular}{|c|c|c|}
\hline № & $\begin{array}{l}\text { EAP-related competences generated by PhDs } \\
\text { (in pre-course survey) }\end{array}$ & $\begin{array}{c}\text { Position } \\
\text { in the rating }\end{array}$ \\
\hline 1. & Good written and oral communication in academic English. & 1 \\
\hline 2. & Useful and frequent language in academic texts. & 12 \\
\hline 3. & Diagrams description. & 19 \\
\hline 4. & The structure of scientific paper for international journals. & 24 \\
\hline 5. & Correct pronunciation of formulae. & 15 \\
\hline 6. & Correct formulation of definitions. & 25 \\
\hline 7. & $\begin{array}{l}\text { Understanding complex grammar and vocabulary structures in } \\
\text { scientific papers. }\end{array}$ & 27 \\
\hline 8. & Writing scientific papers in English. & 2 \\
\hline 9. & Reading and understanding information on professional sites. & 8 \\
\hline 10. & Speaking at the conferences. & 10 \\
\hline \multicolumn{3}{|c|}{ Generic competences generated by PhDs } \\
\hline \multicolumn{3}{|c|}{ Instrumental competences: } \\
\hline 11. & Presentation skills. & 7 \\
\hline 12. & $\begin{array}{l}\text { Ability to understand and analyse the innovations in the specific } \\
\text { field. }\end{array}$ & 4 \\
\hline 13. & Ability to perceive and process a great deal of information. & 3 \\
\hline 14. & Knowledge about papers submission to international editions. & 6 \\
\hline 15. & Ability to search needed information quickly. & 22 \\
\hline \multicolumn{3}{|c|}{ Interpersonal competences: } \\
\hline 16. & Motivation to study Academic English. & 26 \\
\hline 17. & Team working in class. & 11 \\
\hline 18. & $\begin{array}{l}\text { Networking and effective cooperation with peers, teachers, } \\
\text { scientific supervisors. }\end{array}$ & 5 \\
\hline 19. & Ability to perceive constructive feedback. & 14 \\
\hline 20. & Ability to learn from own and peers' mistakes. & 23 \\
\hline 21. & Academic honesty. & 17 \\
\hline
\end{tabular}


Continuation of Table 1

\begin{tabular}{|c|l|c|}
\hline \multicolumn{2}{|c|}{ Systemic competences: } \\
\hline 22. & Independent scientific work. & 21 \\
\hline 23. & Time management. & 18 \\
\hline 24. & Thinking and working effectively. & 20 \\
\hline 25. & Self-evaluation. & 13 \\
\hline 26. & Constant improvement. & 16 \\
\hline 27. & Bringing new ideas in the field. & 9 \\
\hline
\end{tabular}

Table 2 and Table 3 illustrate how PhDs assess the importance of both SSCs and GCs presented in EAP Syllabus at the beginning of the course (1-st column) and the level of these competences development in the framework of their EAP course (2-nd column). The 3-rd column demonstrates the participants' feedback on whether they managed to implement the obtained competences in real-life situations for the two-year period of the EAP study.

Table 2.

Percentage distribution of PhDs' responses as to the importance of specific competences designated in competence-based EAP Syllabus

\begin{tabular}{|l|c|c|c|}
\hline \multirow{2}{*}{$\begin{array}{c}\text { Subject Specific competences of the Syllabus } \\
\text { 'English for Academic Purposes' }\end{array}$} & $\begin{array}{c}\text { Pre-course } \\
\text { survey }\end{array}$ & \multicolumn{2}{|c|}{$\begin{array}{c}\text { Post-course } \\
\text { survey }\end{array}$} \\
\cline { 2 - 5 } & $\begin{array}{c}\text { Importance } \\
\text { of } \\
\text { (\%) } \\
\text { (\%) }\end{array}$ & $\begin{array}{c}\text { Development } \\
\text { within EAP } \\
\text { course } \\
\text { (ranking } \\
\text { scale } \\
\text { from 0 to 5)* }\end{array}$ & $\begin{array}{c}\text { Implementation } \\
\text { in real-life } \\
\text { academic/ } \\
\text { professional } \\
\text { situations } \\
\text { (yes/no) }\end{array}$ \\
\cline { 2 - 5 } $\begin{array}{l}\text { SSC-1. Ability to use academic and } \\
\text { professional English terminology in the } \\
\text { research area. }\end{array}$ & $41.5 \%$ & $89.2 \%(5)$ & $86 \%$ (yes) \\
& & $10.8 \%(3)$ & $14 \%$ (no) \\
\hline $\begin{array}{l}\text { SSC-2. Ability to collect data for research, } \\
\text { systematize and interpret them in English. }\end{array}$ & $38.1 \%$ & $62.1 \%(5)$ & $67 \%$ (yes) \\
\end{tabular}


Continuation of Table 2

\begin{tabular}{|l|c|c|c|}
\hline $\begin{array}{l}\text { SSC-3. Ability to write academic texts of } \\
\text { different genres, taking into account the } \\
\text { purpose and addressee of the message } \\
\text { according to the generally accepted } \\
\text { conventions for academic writing, using the } \\
\text { necessary language resources and means of } \\
\text { logical communication. }\end{array}$ & $\begin{array}{c}72 \%(4) \\
18 \%(3)\end{array}$ & $\begin{array}{c}72 \% \text { (yes) } \\
28 \% \text { (no) }\end{array}$ \\
\hline $\begin{array}{l}\text { SSC-4. Ability to create a Power Point } \\
\text { presentation and present it in concordance } \\
\text { with academic communication requirements. }\end{array}$ & $43.1 \%$ & $71.1 \%(4)$ & $87 \%$ (yes) \\
& & $29.9 \%(3)$ & $13 \%$ (no) \\
\hline $\begin{array}{l}\text { SSC-5. Ability to use techniques of } \\
\text { paraphrasing and summarizing information } \\
\text { from different sources. }\end{array}$ & $15.3 \%$ & $69 \%$ (4) & $66 \%$ (yes) \\
\hline $\begin{array}{l}\text { SSC-6. Ability to identify and apply different } \\
\text { citation styles, compile a list of sources used } \\
\text { in accordance with academic convention. }\end{array}$ & $9.6 \%$ & $17.3 \%(3)$ & $34 \%$ (no) \\
\hline $\begin{array}{l}\text { SSC-7. Ability to linguo-creativity in the } \\
\text { field of science and innovation. }\end{array}$ & $0.8 \%$ & $25.3 \%(2)$ & $4 \%$ (yes) \\
& & $74.7 \%(1)$ & $96 \%$ (no) \\
\hline
\end{tabular}

It should be noticed that both EAP-related and generic competences were not separated in the survey intentionally the participants of research were offered to point out the most significant competences they would like to develop in the course. Although, subsequently the SSCs and GCs were categorized during analyses. 
Table 3.

Percentage distribution of PhDs' responses as to the importance of GCs designated in competence-based EAP Syllabus

\begin{tabular}{|c|c|c|c|}
\hline \multirow{3}{*}{$\begin{array}{l}\text { Generic competences of the Syllabus 'English } \\
\text { for Academic Purposes' }\end{array}$} & \begin{tabular}{|c|} 
Pre-course \\
survey
\end{tabular} & \multicolumn{2}{|c|}{$\begin{array}{l}\text { Post-course } \\
\text { survey }\end{array}$} \\
\hline & \begin{tabular}{|c|}
$\begin{array}{c}\text { Importance } \\
\text { of } \\
\text { competence } \\
(\%)\end{array}$ \\
\end{tabular} & $\begin{array}{c}\text { Development } \\
\text { within EAP } \\
\text { course } \\
\text { (ranking } \\
\text { scale } \\
\text { from 0 to 5)* }\end{array}$ & $\begin{array}{l}\text { Implementation } \\
\text { in real-life } \\
\text { academic/ } \\
\text { professional } \\
\text { situations } \\
\text { (yes/no) }\end{array}$ \\
\hline & 1 & 2 & \begin{tabular}{|l|}
3 \\
\end{tabular} \\
\hline $\begin{array}{l}\text { GC-1. Ability to think abstractly and } \\
\text { critically, generate new ideas in English in } \\
\text { the process of writing a dissertation, } \\
\text { scientific papers, reports. }\end{array}$ & $21.2 \%$ & $\begin{array}{l}30.3 \%(4) \\
44.8 \%(3) \\
24.9 \%(2)\end{array}$ & $\begin{array}{l}58 \% \text { (yes) } \\
42 \% \text { (no) }\end{array}$ \\
\hline $\begin{array}{l}\text { GC-2. Ability to search, systematize and } \\
\text { critically analyse information from various } \\
\text { English-language sources. }\end{array}$ & $22.9 \%$ & $\begin{array}{l}12.4 \%(5) \\
56.5 \%(4) \\
31,1 \%(3)\end{array}$ & $\begin{array}{l}21 \%(\text { yes }) \\
79 \% \text { (no) }\end{array}$ \\
\hline $\begin{array}{l}\text { GC-3. Ability to plan and carry out research } \\
\text { based on a systematic scientific worldview } \\
\text { with the use of modern ICT. }\end{array}$ & $7.8 \%$ & $\begin{array}{l}52 \%(3) \\
48 \%(1)\end{array}$ & $\begin{array}{l}52 \%(\text { yes }) \\
48 \% \text { (no) }\end{array}$ \\
\hline $\begin{array}{l}\text { GC-4. Ability to network with the scientific } \\
\text { community in accordance with the specifics } \\
\text { of the specialism in order to present and } \\
\text { discuss the results of PhD's scientific work } \\
\text { in written and oral forms. }\end{array}$ & $39.4 \%$ & $\begin{array}{l}5.8 \%(5) \\
6.9 \%(4) \\
67 \%(3) \\
20.3 \%(2)\end{array}$ & $\begin{array}{l}24 \% \text { (yes) } \\
76 \% \text { (no) }\end{array}$ \\
\hline $\begin{array}{l}\text { GC-5. Awareness of the scientific ethics } \\
\text { and compliance with academic ethical } \\
\text { requirements. }\end{array}$ & $3.1 \%$ & $\begin{array}{c}67 \%(4) \\
30.2 \%(2) \\
2.2 \%(1)\end{array}$ & $\begin{array}{l}68 \% \text { (yes) } \\
32 \% \text { (no) }\end{array}$ \\
\hline $\begin{array}{l}\text { GC-6. Ability to work and upgrade own } \\
\text { skills in online environment using modern } \\
\text { educational platforms. }\end{array}$ & $11.3 \%$ & $\begin{array}{c}69 \%(4) \\
17.3 \%(2) \\
13.7 \%(1)\end{array}$ & $\begin{array}{l}56 \% \text { (yes) } \\
44 \% \text { (no) }\end{array}$ \\
\hline $\begin{array}{l}\text { GC-7. The ability to learn and work } \\
\text { independently; to learn throughout life. }\end{array}$ & $14.6 \%$ & $\begin{array}{l}15.2 \%(4) \\
84.8 \%(3)\end{array}$ & $\begin{array}{l}98.7 \% \text { (yes) } \\
1.3 \% \text { (no) }\end{array}$ \\
\hline $\begin{array}{l}\text { GC- } 8 \text {. Ability to self-assess and peer-assess } \\
\text { the work of colleagues. }\end{array}$ & $6.9 \%$ & $\begin{array}{l}2.4 \%(5) \\
65.8 \%(4) \\
31.8 \%(1)\end{array}$ & $\begin{array}{l}87 \% \text { (yes) } \\
13 \% \text { (no) }\end{array}$ \\
\hline
\end{tabular}

*Ranking scale indicators: 0 - none; 1 - weak; 2 - satisfactory; 3 - considerable; 4 - strong; 5 - excellent. 
An evaluation of the data from Table 1 allowed us to build a competence rating. It can be seen from Fig. 1 that the first two positions are occupied by EAP-related competences, although, the participants highlighted the importance of generic competences giving next four positions to them.

SSC: Good written and oral communication in academic English.

SSC: The structure of scientific paper for international journals.

GC: Ability to perceive and process a great deal of information.

GC: Ability to understand and analyse the innovations in the specific field.

GC: Networking and effective cooperation with peers, teachers, scientific supervisors.

GC: Presentation skills

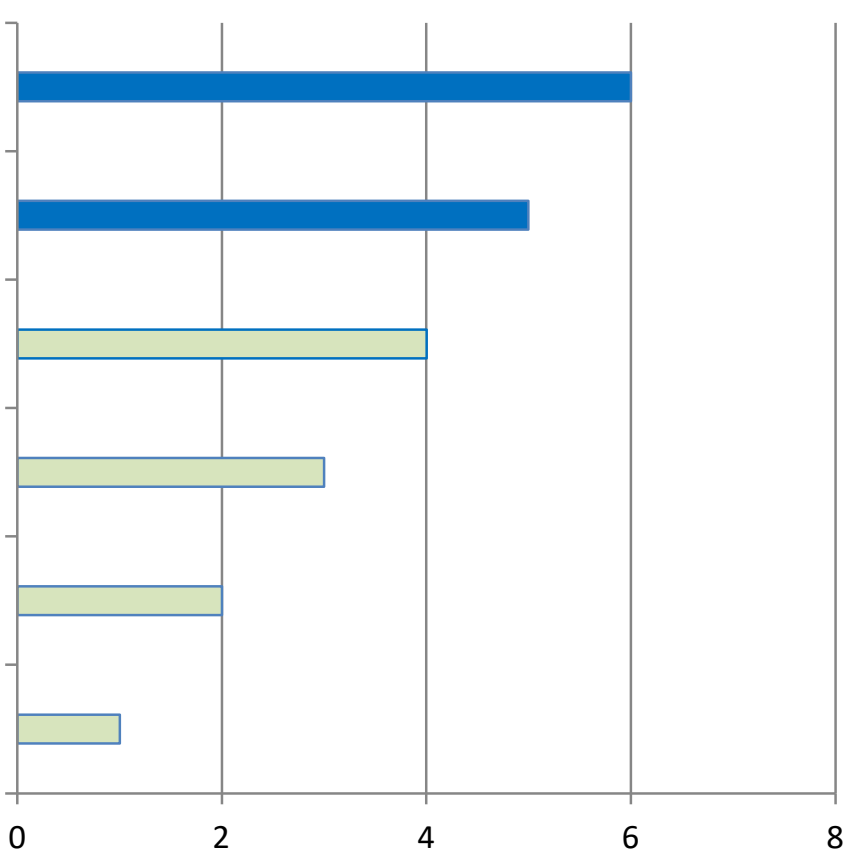
GC - Generic Competence

- SSC - Subject Specific Competence

Figure 1. Top EAP-course competences generated by $\mathrm{PhDs}$ in pre-course survey.

The bar chart (Fig.2) presents the top six competences which are in demand, in $\mathrm{PhD}$ students' judgement. On the other hand, the chart illustrates the comparison between the competences from EAP Syllabus and their practical application in $\mathrm{PhD}$ students' scientific and academic activities.

The comparative analysis of the state of the art shows that EAP-related competences were underestimated by $\mathrm{PhD}$ students at the beginning of EAP study, although the post-course survey demonstrates that the mentioned above competences were successfully developed and actualized by Doctoral students within academic or professional events.

As shown in Fig.2, the PhDs do not only admit the necessity of GCs development since they have included three GCs on the list of prioritized ones in Doctoral curriculum, it is also vital that Doctorate students realise the value of GCs, as they seem to be more motivated to develop them. Such GCs as 'GC-4: Ability to network with 
the scientific community in accordance with the specifics of the specialism in order to present and discuss the results of PhD's scientific work in written and oral forms', 'GC2: Ability to search, systematize and critically analyse information from various English-language sources', 'Ability to think abstractly and critically, generate new ideas in English in the process of writing a dissertation, scientific papers, reports'.

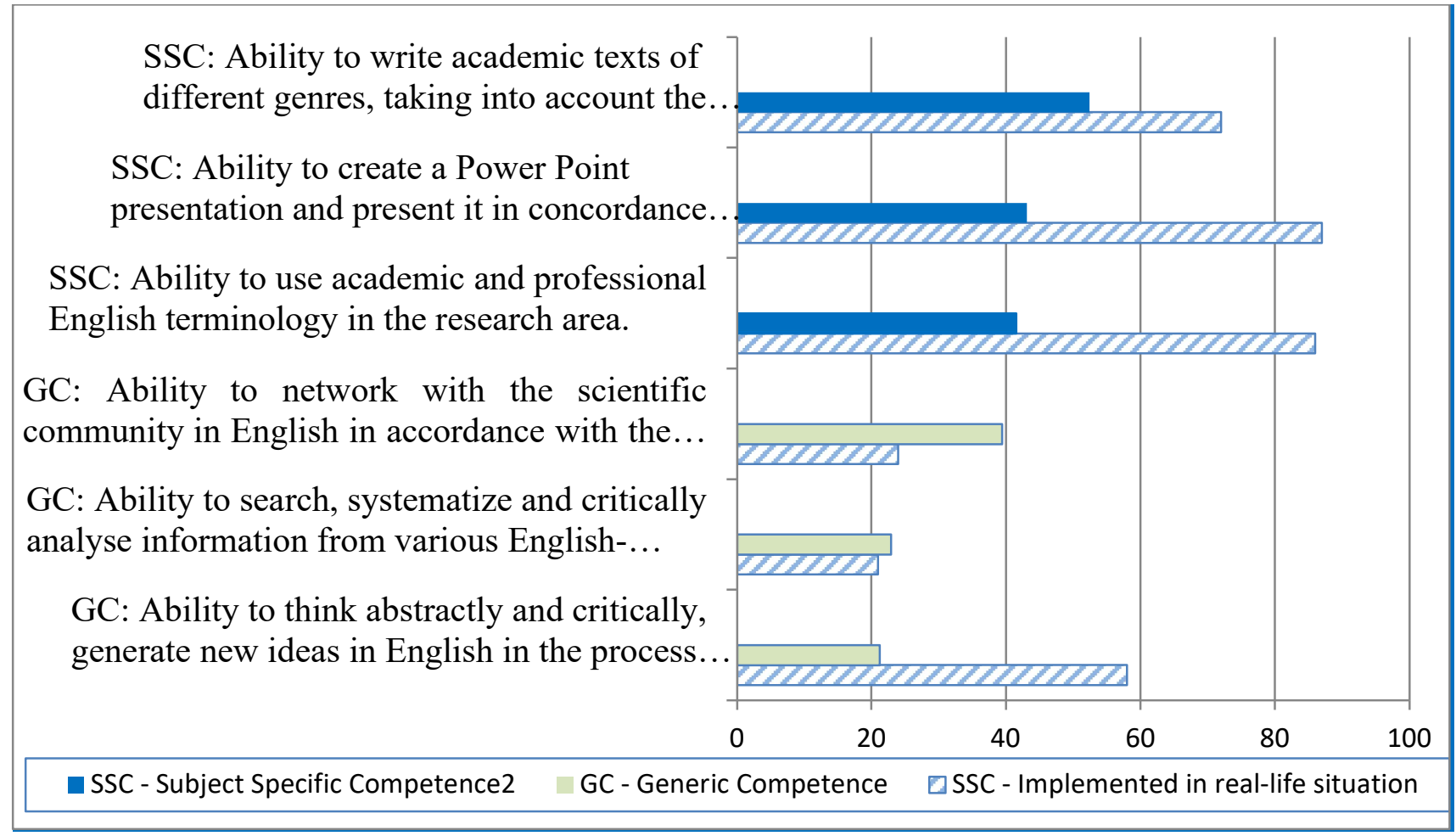

Figure 2. Top SSC and GC competences elicited by PhDs from EAP Syllabus and their real-life implementation.

\section{Conclusion}

This study aimed to develop a greater understanding of both SSCs and GSs which should be developed in the framework of EAP Syllabus for the purpose of assuring profound outcomes in Doctoral training.

Basing on a PhDs' pre-course and post-course surveys, we found that $\mathrm{PhD}$ students are sufficiently aware of the competences which are in demand and require developing. We also identified the most important EAP-related and generic competences offered by EAP Syllabus and generated by PhD students through open-ended questions. It was proposed to include all competences generated by Doctoral students in the EAP Syllabus. On the basis of the research presented it can be recommended to include generic competences in the Doctorial curriculum irrelatively to specialisms of the $\mathrm{PhD}$ 
students. Undoubtedly, the doctoral education cannot be reduced to a list of competences developed by EAP, though we consider them to be an efficient practical tool to help $\mathrm{PhDs}$ in assessing their doctoral experience in international environment. 